\author{
AlENA VALIŠOVÁ \\ Czech Technical University \\ in Prague
}

\title{
TEACHERS' AUTHORITY IN RELATION TO THEIR SOCIAL COMPETENCE
}

\begin{abstract}
Vališová Alena, Teachers' Authority in Relation to Their Social Competence [Autorytet nauczycieli a ich społeczne kompetencje]. Studia Edukacyjne nr 35, 2015, Poznań 2015, pp. 385-394. Adam Mickiewicz University Press. ISBN 978-83-232-2904-9. ISSN 1233-6688. DOI: 10.14746/ se.2015.35.20
\end{abstract}

This discussion contribution deals with the definitions of the terms "social competence" and "teacher authority", explains the meaning of above competence in pedagogical interaction and mentions the possibilities of developing teachers' social abilities and skills as an important part of their professional authority.

Key words: theoretical means of education, teacher authority, social competencies, teaching innovations

\section{Introduction}

In some aspects of the interaction with students the teacher can feel certain problems especially in the competence of expression, in social sensitivity, in discovering and accepting emotions in the capability to give and to accept the feedback, etc.

In the same way, as it is adjudged to individuals or social groups, authority can be related to scientific fields, philosophical theories and even to social institutions. What is the place of contemporary school within this intersection of relations? Does it reflect the crisis of culture, society and democracy? What does one understand under the term of "authority" and what are its features? What is authority based on? To what extent is it neces- 
sary to deal with authority in the period of its indubitable crisis? Is there anything new we can discover in this area? To what extent is it useful to consider authority a pedagogical problem?

Other times an individual feature, that negatively influences the creation of good relations with students, colleagues and chiefs (e.g. intolerance, dominance, unstableness, rigidity, trend to conformity, orientation on fault) can bring many problems. The above mentioned lacks can be eliminated with the help of the high quality pedagogical and psychological preparation of teachers ${ }^{1}$.

\section{Theoretical coherency of the term "social competence of teachers}

The university teacher generally holds the highest status in the "teachers' hierarchy". In many branches of science and research it sometimes happens that some theoretical terms are not unambiguously explained and, of course, the need to define the term "social competence" does not represent any exception to that rule. Its explanation in the professional literature often shows some slight differences. First of all the substance of "social competence" is usually being theoretically developed in coherence with the following related terms: social-psychological competence, work-professional social competence, interpersonal competence, methodical competence of teaching action, interactive competence, communicative competence ${ }^{2}$.

We do not see our task in some kind of a detailed analysis of the above mentioned term; we would rather point out the difficulties connected with its contents definition. In the contemporary pedagogical and psychological literature we can find terms such as ",social competence“ or "social ability" or "social efficiency“. It means adequate use of motor, mental and emotional ways of behavior, capabilities, attitudes and skills that enable to deal successfully with some concrete and important life situations. The term is closely related to exercising ones individual independence (i.e. the skill to organize and independently manage ones own private matters) and to social responsibility (i.e. the responsibility to oneself, to other people and to the whole society). The level of individual independence and responsibility determines the social maturity of a person.

${ }^{1}$ A. Vališová, H. Kasíková a kol., Pedagogika pro učitele, 2. vyd., Praha 2011, p. 445-456.

2 A. Vališová, J. Šubrt, Social competence of teachers - engineers, [in:] VI World Congress on Ćommunication and Arts. Geeolog: COPEC, red. C.C. da Rocha Brito, M. Melany, Projections: WCCA 2013, p. 44-48. 
Social competence related to the teacher's personality may also be considered as a capability of the appropriate teacher's conduct, as an art to perceive processes of the group dynamics, ability to reflect it adequately, and to bring it into line and also as a capability of team work and dealing with adults. Social competence as a result of social maturity is being developed during the ontogenesis of individuality. Not only a child, but also an adult can continuously develop the quality of their social capability through continued social learning, training and repeating.

\section{Etymology of teacher authority}

Problems of authority and manipulation, freedom and responsibility are usually discussed in connection with aspects related to teacher's social competence. After all, do we really need authority and manipulation in education? What kind of relation between freedom and responsibility can be found in the educational process? How much can these relations influence the quality of young peoples' social competence developing and the ways of their social behavior?

In relation to the clarification of the term "authority" we must realise the need of scientific interpretation of the term (not only the term as such, but also the related terminology). Authority as the widest and most complex area can be interpreted from the point of view of the individual fields of science (e.g. school as an institution and its authority can be perceived in terms of sociology, psychology as well as pedagogy.) It is actually always the particular point of view and selected aspects which are being judged pedagogical interpretation can differ from, say, political interpretation. However, we can state that philosophical and political aspects penetrate into pedagogical point of view.

Looking at the etymology of the word authority we discover that the Latin equivalent "auctoritas" bears a whole set of positive meanings like: supportive, guarantee, certainty, reliability, trustworthy and many other. The relating word "auctor" means among other: helper, supporter, ideal, example, predecessor. The root of both words - augo - expresses the verbs: to support growing, enhance, multiply, thrive, enrich, endow. Where are the terms like oppression, tyranny, violence or force? The preceding positive connotations of the word authority present a sound argument against the ultraliberal destroyers of authority. The reality and historic development of a society often neglect the etymology by moving and changing the meanings of words (the concept of the word "authority" was influenced especially by 
sociological and politological essays on the relationships between power versus authority, authority versus government, authority versus social pressure) $)^{3}$.

The term "authority" is usually understood on three levels: firstly, as general respect, influence, power, admiration. Secondly, as a publicly recognised expert, influential personality and last but not least, authority representing state, science, national symbols, offices, law and police force. Influence, dominance, control and competence are among the most frequent synonyms to the word "authority".

The term ",authority" is connected with expressions such as duty, power, fear, manipulation, service, career, competence, responsibility, rules, order, discipline, obedience, etc. We do not want to analyze here these very complicated relations. We would only try to point out some general preconditions of the "natural authority":

- high professional and qualification level

- art of leading and managing a working team

- capability to communicate and cooperate with a group

- capability to avoid conflicts and possibly to solve them

- art of non-violent arguing and conduct

- capability to motivate other people towards output

- art of tolerance, humor, strictness and perseverance combination

- capability to cope with own emotional problems and those of other people

- art of determining rules for interpersonal relations and work responsibilities and common respect for them

- art of showing appreciation and giving praise and express criticism

- general natural image and cultured behavior.

\section{The types of authority and the term "global authority"}

What are the types of authority? What are the problems of classifying authority? The most serious issue is the actual identification of valid classifying criteria.It is not a complete survey, which is our biggest concern and moreover, some classifying differences are mutually overlapping. Regarding the fact that we will use some terms in thinking about the problems of authority in education, it is inevitable to mention the criteria at least briefly.

${ }^{3}$ A. Vališová, Jak získávat, udržet a neztrácet autoritu, Praha 2010, p. 40-42. 
The first criterion to consider could be genetic (possibly differentiates between the authority natural and authority gained). Another significant criterion is generally the social point of view. According to social status, we can classify authority as personal, positional and functional. With regard to the effects in the behaviour of social environment, we can determine real authority and apparent authority. In view of social prestige, authority is divided into formal and informal type. According to the bearer within a historic development we recognise parental authority, authority of the older, authority of governors, religious, official or scientific authority. Last but not least, we can speak about statutory, charismatic, special and moral authority.

A complicated task felt by each of us is to find the scope of the relations between the individual types of authority while using them in particular situations - in professional and personal life. The emphasis placed on proper links and balance in using statutory, expert, moral and personal (charismatic) authority becomes a challenge even in the school and family conditions. A person can represent a great degree of authority while another is respected due to his/her human and moral qualities where the others are recognised only by their statutory authority and consequently, his/her position of power. A good combination of all kinds of authority, although conditioned by individual situations as well as by time constraints, is labelled by the term "global authority".

"Authority can be generally determined as a significant form of realising power which is based on more or less general recognition of authority, legality, certain influence of a person, institution or a group. It is a commonly accepted fact that authority differs from power which is based on direct enforcement, by its legalisation - i.e. to a certain extent, a particular person, institution or group is entitled to carry out the power, especially stimulating, enforcing, organising and controlling human activities as well as expressing and co-ordinating individual and group interests" 4 .

\section{What are the relations between teacher authority and education - looking for interrelations}

When specifying the term "authority" the scientific interpretation must be necessarily taken into account. From the professional literature it follows that there is no consentient interpretation of the authority conception and that it is a very complicated term which is often used very freely, inaccu-

4 S. Kučerová, Problém vztahu autority, hodnot a ideáli̊ pohledem současné mládeže, [in:] Autorita ve výchově - vzestup, pád nebo pomalý návrat, red. A. Vališová a kol., Praha 1999, p. 69-85. 
rately and which sometimes is even misinterpreted (the authority is considered to be personal, natural and is also connected with power, rulers, official or directive authority; this term is also used in relation to authoritative conduct, authority of supervisors, adults, parents and older people, educator's and teacher's authority, authoritative, autocratic and authoritarian style of education, authoritarian personality, anti authoritative pedagogy, authoritative style of management and social pressure).

Unfortunately the confusion concerning its contents, however, belongs to characteristic features of the modern time and enables darkening or covering of an important range of other terms associated with authority (e.g. freedom, discipline, manipulation, responsibility, blame, influence, power, values, standards). The elaboration of a more complex theoretical basis will follow in the present grant project placing accent on comparison of theoretical papers from abroad 5 .

The process of looking for interrelations between the education and authority can be viewed and discussed at three interlinked levels and the approach to each of them depends on the contents of the following points of view:

a) macro-social (involves above all the interrelation between authority and education in the society in its broadest context);

b) micro-social or interpersonal (it concerns largely topics as values, conduct standards, rules and principles which are determined e.g. by family life or rules of conduct at school);

c) interpersonal (it is aimed at investigation of the process of learning standards and value orientation from each other and the means largely influencing individuals).

Attention in the present project will be in particular paid to the interpersonal level. We are convinced that this will be satisfactorily dealt by the proposed research investigation as it is important for our purposes. How the relation between the authority and the education can be expressed? The standards and values of the society are based on the authority and they can also be enforced through it. The way of their presentation is at the same time a matter of the educational process in coherence with educational styles, the approach of parents, the kind of management and the applied degree of emotional relation between adults and children - teachers and students.

Education and authority can be perceived as being of the same origin and therefore authority based on this thesis cannot be separated from education - in both cases it concerns the presentation of values and standards of the society. 


\section{The authority as social relationship between student and teacher}

The above mentioned contemplation reflects the constant strive for finding an answer to one of the most essential questions: to what extent should the school, parents, adults intervene in a child's development? Each type of education is, to a certain extent, authoritative in facilitating the young individual's search for a place in the world of adults, teaching him/her to respect the rules which are important for his/her development and for the functioning of the social group. The practice - not only educational one strongly indicates that school, family and society fail to complete its tasks without authority and reasonable rules thus, losing its value, firm position, securities and basic functions.

People sometimes state that a person either has authority or lacks it. This opinion perceives authority as a human characteristic feature regardless of its dynamics and social aspects. Thinking of authority as of the mutual relationship between the bearer of authority (e.g. a person who influences people around him/her) and the receiver (e.g. the "addressee" of the influence, who respects the bearer and accepts him/her to a certain extent), we have to keep two basic aspects in mind:

a) aspect of relativity - an individual gains authority within a limited period, in relation to his/her social surroundings, towards certain people, particular groups (e.g. at work, in family, in a group of special interest). Not necessarily has the person the same "extent" of authority in different spheres of his/her influence, in different social groups, in limited time and towards particular members of the group. Social conditioning of authority casts doubt in understanding authority as a human feature which a person is endowed, regardless of his/her surrounding sphere (perhaps there exist such features which help a person to gain and keep authority);

b) aspect of asymmetry - the bearer of authority has a decisive, overwhelming impact creating the relationship of superiority and inferiority, the dimension of leadership and following. The asymmetry of a relationship can originate in a formal position of the bearer as well as in his/her informal position, respectively in the combination of both. The receiver of authority conditions the existence of authority by respecting the bearer and by accepting his/her influence ${ }^{6}$.

Tempting to understand authority as a social relationship we are perhaps able to better explain its links with education. However, authority can be interpreted as a "play" of social roles where one part of the relationship is

${ }^{6}$ A. Vališová, H. Kasíková a kol., Pedagogika pro učitele, p. 451. 
formed by the "leading" role while the other by the "following" role (e.g. parent - child, teacher - pupil, lecturer - student). Both roles help to form each other, they tend to be mutually balanced, they are complementary, although asymmetrical (they cannot be identified with each other).Eventually, it is essential to respect the specificity of social roles and competencies ensuing from these roles. The dynamics of relations in the educational process depends on a co-participation of all the present actors -teachers and students.

The conception of teacher pedagogical and psychological preparation could probably respect the following requirements:

a) balance between particular components of socio-professional preparation (knowledge, activities, values);

b) balance between theoretical and practical components of psychological and pedagogical preparation;

c) balance between empirical (based on experience) and cognitive (based on knowledge) activities.

From the strategic point of behavior, the teachers professional preparation should result in:

- development of social competence;

- creation of teacher's independence in action.

There is a range of many other questions concerning professional preparation of teachers and their authority. Is it possible to reach high professionalism within the framework of preparatory or another education or only in practice? Has introspection a place in the professional preparation of teachers? What role is played by psychological and pedagogical lessons in development of teacher social competence? What methodical principles can be used for development of their social capabilities?

It is increasingly evident from practice (not only educational) that the school, family and society are not able to fulfill its role without authority and a meaningful regime, loose their value, stability, certainty and also basic functions. We infer from experience that this topic is up-to-date not only in our country.

\section{Conclusions}

The term authority is also in coherence with such expressions as discipline, power, freedom, responsibility, morality, law, duty, tolerance, rule, fear ... True authority, however, cannot be only sought in schools but also among parents, citizens, politicians, in the laws, legal system and in the so- 
cial system ${ }^{7}$. This is the only way in which young people can accept the faith and confidence in authority. School as an institution, school management and a team of educators can develop many positive features in young people but what they certainly cannot do is to replace the family and society.

Phenomenon of the authority and the recommended decalogue:

- Authority as a multidimensional and multidisciplinary conception.

- The conception of authority does not constitute an isolated problem.

- Authority does not mean authoritarianism.

- Authority is not in contradiction with criticism.

- Authority does not necessarily lead to conformity.

- Authority expresses relationship.

- The aspect of relativity and asymmetry in perception of the authority.

- Specifics of accepting and development of authority in different social environment.

- Development of authority as a long-tem process.

- Danger of relativization of the authority in social context.

I think that the problems are actual not only in our country - in the Czech Republic.

\section{BIBLIOGRAPHY}

Adorno T.W. et al., The Authoritarian Personality, Harper Brothers, New York 1950.

Andres P., Vališová A., Institucionální vzdělávání učitelů - techniku․ Lifelong Learning - Celoživotní vzdělávání, Mendelova univerzita, Institut celoživotního vzdělávání, Brno 2014, 3, 3 .

Arendt H., Krize kultury, Mladá fronta, Praha 1994.

Fuchs A., Autorita, Melantrich, Praha 1930.

Kolář Z., Raudenská V., Rymešová J., Šikulová R., Vališová A., Výkladový slovník z pedagogiky, Grada Publishing, Praha 2012.

Kron F.W., Grundwissen der Pedagogik, München 1989.

Kučerová S., Problém vztahu autority, hodnot a ideálů pohledem současné mládeže, [w:] Autorita ve výchově - vzestup, pád nebo pomalý návrat, red. A. Vališová a kol., Karolinum, Praha 1999.

Maccoby E.E., Martin J.A., Socialization in the context of the family: parent-child interaction, [w:] Handbook of Child Psychology: Socialization, personality and social development, Vol. 4, red. E.M. Hetherington, Wiley, New York 1983.

Novotný P., Autoritářství jako jedna z determinant výkonu učitelské profese, Pedagogika, 1997, $47,3$.

Rich J.M., Discipline and Authority in School and Family, New York 1982.

7 A. Vališová, Authority in the Context of the Intergenerational Relations, Studia Edukacyjne, 2013, 29, p. 273-285. 
Skalková J., K problematice autority ve vývoji pedagogického myšlení - ve 20. století a na počátku 21. Století, [w:] Relativizace autority a její dopady na současnou mládež, red. A. Vališová, M. Bratská, B. Sliwerski, ISV, Praha 2005.

Sliwerski B., Pozycja nauczyciela w szkole a jego autorytet, LU, Lodž, 2003.

Vališová A., Jak získávat, udržet a neztrácet autoritu, Grada Publishing, Praha 2008.

Vališová A., Jak získávat, udržet a neztrácet autoritu, Grada Publishing, Praha 2010.

Vališová A., a kol. Autorita a proměny jejîho pojetí v edukačním prostředí, Karolinum, Praha 2011.

Vališová A., a kol. Autorita vedukační a sociální práci, Univerzita Pardubice, Pardubice 2012.

Vališová A., Authority in the Context of the Intergenerational Relations, Studia Edukacyjne, 2013, 29.

Vališová A., Kasíková H. a kol., Pedagogika pro učitele, 2. vyd., Grada Publishing, Praha 2011.

Vališová A., Šubrt J., Social competence of teachers - engineers, [w:] VI World Congress on Ćommunication and Arts, red. C.C. da Rocha Brito, M. Melany, Projections: WCCA 2013 - Geeolog: COPEC.

Weber M., Autorita, etika a společnost, Mladá fronta, Praha 1997.

Wróbel A., Wychowanie a manipulacja, Oficyna Wydawnicza Impuls, Kraków 2006. 